\title{
Effect of Selected Botanicals against Leaf Spot (Alternaria brassicae) of Cabbage (Brassicae oleracea var. Capitata $\mathrm{L}$ )
}

\author{
Dasari Sreevarshini*, Vaka Siva Kumar, Sobita Simon and Abhilasha A. Lal
}

Department of Plant Pathology, Sam Higginbottom University of Agriculture, Technology and Sciences, Prayagraj, Uttar Pradesh, India

*Corresponding author

Keywords

Cabbage, Alternaria

brassicae,

Botanicals,

Leaf spot

\section{Article Info}

Accepted:

12 November 2019

Available Online:

10 December 2019
Cabbage (Brassica oleraceae var. Capitata L.) is contemplated as second most important vegetable belonging to the family brassicaceae. Alternaria leaf spot of cabbage is prevalent in all the cabbage growing states and is one of the major biotic problems, which limits the production of cabbage and quality of produce. The experiment for management practices on leaf spot of cabbage using botanicals was conducted during Rabi season. The minimum disease intensity was recorded in foliar sprays of Eucalyptus globulus @ 10\% (30.40\%) followed by Azadirachta indica@15\% (31.4\%), Lantana camara@15\% (32.40\%), Ocimum sanctum @ 15\% (34.8\%), Cyperus rotundus@15\% (37.4\%), as compared to treated (27.5 $\%)$ and untreated (43.8 \%) checks. Maximum fresh head weight was recorded in Eucalyptus globulus $(0.80 \mathrm{~kg})$ followed by Azadirachta indica $(0.65 \mathrm{~kg})$, Lantana camara (0.64 kg ), Ocimum sanctum (0.56 kg ), Cyperus rotundus $(0.52$ $\mathrm{kg})$, as compared to treated $(1.01 \mathrm{~kg})$ and untreated $(0.46 \mathrm{~kg})$ checks. Maximum yield was recorded in Eucalyptus globulus (26.72 tonnes/ha) followed by Azadirachta indica (24.44 tonnes/ha), Lantana camara (22.88 tonnes/ha), Ocimum sanctum (21.27 tonnes/ha), Cyperus rotundus (17.77 tonnes/ha), as compared to treated (33.96 tonnes/ha) and untreated (14.71 tonnes/ha) checks.

\section{Introduction}

Cabbage (Brassica oleracea var. capitata L.) is contemplated as second most important vegetable belonging to the family Brassicaceae known as a leafy green or purple biennial plant. The cabbage plant, Brassica oleracea, is an herbaceous annual or biennial vegetable in the family Brassicaceae grown for its edible head (Singh et al., 2006).Cabbage is an superior source of vitamin $\mathrm{K}$, vitamin $\mathrm{C}$ and vitamin $\mathrm{B}_{6}$. It is a further good source of manganese, dietary fiber, potassium, vitamin $\mathrm{B}_{1}$, folate and copper. Additionally, cabbage is a vigorous source of choline, phosphorus, vitamin $\mathrm{B}_{2}$, magnesium, calcium, selenium, iron, pantothenic acid, protein (Nilsson et al., 2006; 
Kusznierewicz et al., 2008). It is the major source of vegetable in the world and constitutes an important part of diet. Daily per capita consumption of vegetables in the country is only $145 \mathrm{~g}$, which is much less than the requirement of about $285 \mathrm{~g}$ for a balance diet (ICMAR, 1998). The cabbage crop is affected by various fungal as well as bacterial diseases like damping off, club root, downy mildew, Sclerotinia rot, black leg, black rot, soft rot and Alternaria blight or Alternaria leaf spot. The disease Alternaria leaf spot of cabbage is prevalent in all the cabbage growing states and is one of the major biotic problems, which limits its production and also quality of produce. There are two species of Alternaria which cause serious damage in cabbage: Alternaria brassicae and Alternaria brassicicola, they can survive saprophytically outside of the host and diseased crop debris (Yadav et al., 2014). Several fungicides and botanicals belonging to various groups are recommended for the management of Alternaria leaf spot of cabbage. Now-a-days farmers are using only the chemical fungicides for managing the disease, but it has the negative im act on the environment and develops resistant in pathogen. So, due to these reasons use of specific chemical fungicides with recommended dosages and botanicals will not harm the environment and also were effective in controlling the disease (Yadav et al., 2014).

\section{Materials and Methods}

The present investigation was carried out at Central Research Field, Department of Plant Pathology, SHUATS, Prayagraj (U.P.) during Rabi season. The experiment was conducted in Randomized Block Design with 7 treatments. The treatments were replicated three times. Treatments were randomly arranged in each replication divided into 21 plots. The plot size was $2 \times 2 \mathrm{~m}$. Foliar spray of botanicals were started at onset of the disease and repeated two sprays. The seven treatments were taken as: Mancozeb $(0.2 \%)$, Azadirachta indica (15\%), Eucalyptus globulus (10\%), Ocimum sanctum (15\%), Lantana camara (15\%), Cyperus rotundus $(15 \%)$ and control were used for management of disease. Yield, headweight data was recorded and PDI was calculated after each spray by using 0-9 disease rating scale on the basis of percentage area of foliage infected by the pathogen.

\section{Isolation of the pathogen}

The pathogen was isolated from the disease infected plants and it was identified as the Alternaria brassicae. Alternaria leaf spot of cabbage infected leaves were collected from experimental field of SHUATS. The infected leaves were cut into small pieces $\left(0.5 \mathrm{~cm}^{2}\right)$ surface sterilized with sodium hypochlorite $(0.1 \%)$ for $15-30$ seconds, rinsed with three changes of sterile distilled water to remove the disinfectant and blotted dry. The sterilized pieces were plated (4 pieces/dish) on potato dextrose agar (PDA) medium in Petri dishes under aseptic conditions and incubated at 25 ${ }^{\circ} \mathrm{C}$ for 2 weeks.

For obtaining sufficient quantity of inoculums, pure cultures were obtained by sub culturing. For this purpose, small bits of the fungus were taken at the tip of a sterilized needle and transferred aseptically to the centre of fresh PDA medium in Petri dishes. The dishes were incubated for 2 weeks at $25{ }^{\circ} \mathrm{C}$ in the dark.

\section{Preparation of botanicals}

For preparation of extract 150 g leaves were taken in a clean blender and blended without water, the pulverized leaves tissue was filtered through three-fold of muslin cloth and $100 \%$ pure filtrate was used as an extract in the ratio of $1: 1(\mathrm{w} / \mathrm{v})$ of seed and solution (Table 1$)$. 


\section{Results and Discussion}

The experimental results of the present investigation reveals that minimum per cent disease intensity was recorded in $\mathrm{T}_{2}$ Eucalyptus globulus @ 10\% (30.40 \%)

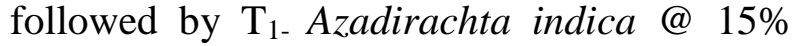
(31.4\%), $\mathrm{T}_{4}$ - Lantana camara@ 15\% (32.40 $\%), \mathrm{T}_{3}$ - Ocimum sanctum @ 15\% (34.8\%), $\mathrm{T}_{5}$ - Cyperus rotundus @15\% (37.4\%), as compared to $\mathrm{T}_{6}$ - treated $(27.5 \%)$ and $\mathrm{T}_{0}$ untreated $(43.8 \%)$ checks. The maximum fresh weight of head of cabbage was observed in $\mathrm{T}_{2}$ - Eucalyptus globulus $(0.80 \mathrm{~kg})$ followed by $\mathrm{T}_{1}$ - Azadirachta indica $(0.65 \mathrm{~kg}), \mathrm{T}_{4}$ Lantana camara $(0.64 \mathrm{~kg}), \mathrm{T}_{3}-$ Ocimum sanctum $(0.56 \mathrm{~kg}), \mathrm{T}_{5}-$ Cyperus rotundus $(0.52 \mathrm{~kg})$, as compared to $\mathrm{T}_{6}$ - treated $(1.01$ $\mathrm{kg})$ and $\mathrm{T}_{0}$ - untreated $(0.46 \mathrm{~kg})$ checks. Maximum yield was recorded in $\mathrm{T}_{2^{-}}$ Eucalyptus globulus (26.72 tonnes/ha) followed by $\mathrm{T}_{1}$ - Azadirachta indica (24.44 tonnes/ha), $\mathrm{T}_{4}$ - Lantana camara (22.88 tonnes/ha), $\mathrm{T}_{3}-$ Ocimum sanctum (21.27 tonnes/ha), $\mathrm{T}_{5}$ - Cyperus rotundus (17.77 tonnes/ha), as compared to $\mathrm{T}_{6}$ - treated (33.96 tonnes/ha) and $\mathrm{T}_{0}$ - untreated (14.71 tonnes/ha) checks. Reported yield of mustard seeds was significantly highest in Eucalyptus spray.

Probable reasons for such findings may be that the presence of essential oils (monoterpene $\alpha-$ pinene, $p$-cymene and $y$-terpinene) in Eucalyptus may have prevented the hyphal growth and sporulation of Alternaria brassicae. It may have also interrupted the nutrient uptake and induced lysis. These are also responsible for altering the fungal physiology by inducing changes in cell wall compositions, plasma membrane disruption, mitochondrial structure, membrane.

Table.1

\begin{tabular}{|l|l|l|l|l|}
\hline S.no & \multicolumn{1}{|c|}{ Treatments } & \multicolumn{1}{|c|}{$\begin{array}{c}\text { Disease } \\
\text { intensity } \mathbf{( \% )}\end{array}$} & $\begin{array}{c}\text { Head weight } \\
(\mathbf{k g})\end{array}$ & Yield (t/ha) \\
\hline $\mathbf{T}_{\mathbf{0}}$ & Control ( untreated check) & 43.80 & 0.46 & 14.71 \\
\hline $\mathbf{T}_{\mathbf{1}}$ & Azadirachta indica @ 15\% & 31.40 & 0.65 & 24.44 \\
\hline $\mathbf{T}_{\mathbf{2}}$ & Eucalyptus globulus @ 10\% & 30.40 & 0.80 & 26.72 \\
\hline $\mathbf{T}_{\mathbf{3}}$ & Ocimum sanctum @ 15\% & 34.80 & 0.56 & 21.27 \\
\hline $\mathbf{T}_{\mathbf{4}}$ & Lantana camara @ 15\% & 32.40 & 0.64 & 22.88 \\
\hline $\mathbf{T}_{\mathbf{5}}$ & Cyperus rotundus @ 15\% & 37.40 & 0.52 & 17.77 \\
\hline $\mathbf{T}_{\mathbf{6}}$ & Mancozeb @ 0.20\% (treated check) & 27.50 & 1.01 & 33.96 \\
\hline & $\quad$ SEd \pm & 0.61 & 0.06 & 0.37 \\
\hline & C.D. $(\mathrm{P}=0.05)$ & 1.89 & 0.18 & 1.1 \\
\hline
\end{tabular}

The result allows to conclude that the contrary to the problems associated with the use of synthetic chemicals, botanicals are environmentally non pollute, indigenously available, easily accessible, non phytotoxic, systemic ephemeral, readily biodegradable, relatively cost effective and hence constitute a suitable plant protection in the strategy of biological management of disease. Eucalyptus globulus at $10 \%$ concentrations were found as best treatment to control of Alternaria leaf spot of cabbage and also gave higher yields as par compared with Mancozeb (Treated check). Since present day economists are advising for net return concept, Eucalyptus globulus can be recommended and keeping a point view of environmental safety can also recommended to the farmers for the efficient management of Alternaria leaf spot of cabbage. 


\section{References}

ICMAR. Food and Agricultural Organization of United Nation: Economic and ssSocial Department. The Statistical Division. 1998.

Kusznierewicz, B., Bartoszek, A. and Wolska, L. (2008). Partial characterization of white cabbages (Brassica oleracea var. capitata f. alba) from different regions by glucosinolates, bioactive compounds, total antioxidant activities and proteins. LWT - Food Sciences and Technology, 41:1-9.

Nilsson, J., Olsson, K. and Engqvist, G. (2006). Variation in the content of glucosinolate, hydroxycinnamic acids, carotenoids, total antioxidant capacity and low-molecular-weight carbohydrates in Brassica vegetables. Journal of the Science of Food and Agriculture, 86: 528-38.

Singh, P. C. and Singh, D. (2006). In vitro evaluation of fungicides against Alternaria alternata. Annals of Plant Protection Sciences, 14 (2): 500-502.

Yadav, C.L., Kumar, N. and Kumar, R. (2014). Effect of seed treatments with fungicides bio-agents and botanicals against Alternaria leaf spot in cabbage (Brassica oleracea var. capitata L.). Trends in Biosciences, 7(23): 38233827.

\section{How to cite this article:}

Dasari Sreevarshini, Vaka Siva Kumar, Sobita Simon and Abhilasha A. Lal. 2019. Effect of Selected Botanicals against Leaf Spot (Alternaria brassicae) of Cabbage (Brassicae oleracea var. Capitata L). Int.J.Curr.Microbiol.App.Sci. 8(12): 1426-1429.

doi: https://doi.org/10.20546/ijcmas.2019.812.172 